\title{
Male-Produced (-)- $\delta$-Heptalactone, Pheromone of Fruit Fly Rhagoletis batava (Diptera: Tephritidae), a Sea Buckthorn Berries Pest
}

\author{
Vincas Būda ${ }^{1}$, Laima Blažytė-Čereškienè ${ }^{1}$, Sandra Radžiutė ${ }^{1}$, Violeta Apšegaite் ${ }^{1}$, \\ Patrick Stamm ${ }^{2}$ D, Stefan Schulz ${ }^{2}$ D , Dominykas Aleknavičius ${ }^{1}$ and Raimondas Mozūraitis ${ }^{1, *(1)}$ \\ 1 Laboratory of Chemical Ecology, Nature Research Centre, Akademijos 2, LT-08412 Vilnius, Lithuania; \\ vincas.buda@gamtc.lt (V.B.); laima.blazyte@gamtc.lt (L.B.-Č.); sandra.radziute@gamtc.lt (S.R.); \\ violeta.apsegaite@gamtc.lt (V.A.); dominykas.aleknavicius@gamtc.lt (D.A.) \\ 2 Institute of Organic Chemistry, Technische Universität Braunschweig Hagering 30, 38106 Braunschweig, \\ Germany; p.stamm@tu-braunschweig.de (P.S.); stefan.schulz@tu-bs.de (S.S.) \\ * Correspondence: raimondas.mozuraitis@gamtc.lt
}

Received: 25 January 2020; Accepted: 18 February 2020; Published: 23 February 2020

\begin{abstract}
The plantation area of sea buckthorn (Hippophae rhamnoides L.) is expanding in many European countries due to increasing demand for berries, thus creating suitable conditions for the rapid expansion of the fruit fly Rhagoletis batava, a pest of economic importance. To decrease insecticide use, effective means for pest population monitoring are required, including the use of pheromones. Male fruit flies emit (-)- $\delta$-heptalactone as revealed by gas chromatography-mass spectrometry analyses of samples obtained using headspace methods. The two enantiomers of $\delta$-heptalactone were synthesized using enantioselective synthesis. A gas chromatography-electroantennographic detection analysis of both stereoisomers revealed that only (-)- $\delta$-heptalactone elicited electrophysiological responses, whereas no signal was registered to $(+)-\delta$-heptalactone in fruit flies of either sex. In the field assay, traps baited with (-)- $\delta$-heptalactone caught significantly more fruit flies compared with the unbaited traps. Our results are the first to demonstrate the efficacy of (-)- $\delta$-heptalactone as a bait for trapping $R$. batava. As a behaviorally attractive compound to $R$. batava fruit flies of both sexes, $(-)-\delta$-heptalactone is attributed to aggregation pheromones. This is the first report of an aggregation pheromone within the genus Rhagoletis.
\end{abstract}

Keywords: Rhagoletis batava; pheromone identification; synthesis; bioassay; field trapping; SPME; GC-EAD; GC-MS

\section{Introduction}

Rhagoletis batava Hering (Diptera: Tephritidae) fruit flies are pests of economic importance that cause damage to sea buckthorn (Hippophae rhamnoides L. Rosales: Elaeagnaceae) berries. After a female fruit fly lays eggs on a sea buckthorn berry, the hatched larvae enter a berry and feed inside; eventually, infested berries change color from natural yellow to black and lose their commercial and nutritional value $[1,2]$. As damaged berries remain stuck to branches alongside undamaged berries, harvesting both decreases the value of the total yield. Sea buckthorn is cultivated in European countries due to the multiple ecological and medicinal benefits of sea buckthorn [3,4]. The cultivar was introduced from Asia and, since introduction, the plantation area has increased significantly, thus providing conditions conducive to spreading natural pests such as R. batava.

Demand for sea buckthorn berries for food, medical purposes and cosmetics is increasing [3,5-8] and supply has not been able to satisfy this demand $[9,10]$. The production of organic sea buckthorn is a special demand. However, to date, no environmentally friendly means of pest control are available 
for this species; thus, insecticides are widely used for yield protection. Current tools available for monitoring $R$. batava populations are ineffective. Yellow sticky traps are still recommended and used [11] and the use of nonspecific attractant has also been recently reported [12]. Pheromone identification could fill this gap and be applied for pest population monitoring and potentially contribute to environmentally friendly pest control. The latter application seems especially promising, as males mainly produce pheromones that affect the behavior of females in a few species of genus Rhagoletis fruit flies $[13,14]$.

The pheromone mediating attraction of Rhagoletis flies has been identified for walnut husk fly, Rhagoletis completa Cresson (Diptera: Tephritidae). Two lactones, namely $\delta$-hexalactone and $\delta$-heptalactone at the ratio $4: 6$, were released exclusively by males and showed significant attractiveness under field experiments [15]. Unfortunately, the sex of the specimens caught in the traps was not determined; hence, information is insufficient to determine whether one or both sexes responded to the lactones. Raptopoulos et al. [16] proposed that pheromone produced by Rhagoletis cerasi (Diptera: Tephritidae) males is a multicomponent blend; however, the chemical composition of volatiles remains putative. Up to date, pheromones of $R$. batava have not been previously studied.

The purpose of this study was to isolate and identify pheromones in R. batava, to synthesize the compound(s) and to evaluate the biological activity of synthetics both on olfactory receptors and on a behavioral level under laboratory as well as field conditions.

\section{Materials and Methods}

\subsection{Insects}

For the electrophysiological recordings, sea buckthorn fruit flies, Rhagoletis batava, were collected as puparia from the soil under sea buckthorn shrubs in May 2019 at an organic sea buckthorn Hippophae rhamnoides L. plantation (24 ha area, global positioning system (GPS) coordinates: $55^{\circ} 15^{\prime} 12.179^{\prime \prime} \mathrm{N}$, $25^{\circ} 26^{\prime} 23.049^{\prime \prime}$ E) in Stacijava village, Molètai district, Lithuania. Each puparium was placed in an individual $14 \mathrm{~mL}$ glass vial containing wet $3 \mathrm{~cm}^{2}$ filter paper and corked by foam stoppers. Vials were placed in a Fitotron climate chamber (Weiss Gallenkamp, Loughborough, UK), under $20-24{ }^{\circ} \mathrm{C}$, for a 16:8 light:dark photoperiod and 65-75\% relative humidity. Twice per week, $2-3$ drops of water were added to the filter paper to maintain high humidity inside the vial. Emerged adults were maintained in the same vials in a walk-in climate room at $18-20^{\circ} \mathrm{C}$, natural daylight photoperiod, $50-60 \%$ relative humidity and fed on $10 \%$ sugar solution in water.

The flies were sexed by visually examining the abdomen tip; the presence of an ovipositor indicated that the specimen was a female. The sexed flies were maintained in individual vials under the same conditions described above.

\subsection{Sampling of R. batava-Produced Volatiles}

Solid phase micro-extraction (SPME) was used to sample the headspace of the fruit flies. Before each collection, the SPME fibers coated with polydimethylsiloxane-divinylbenzene polymer (DVB/PDMS, $65 \mu \mathrm{m}$ coating layer thickness, Supelco, Bellefonte, PA, USA) were routinely purified at $240{ }^{\circ} \mathrm{C}$, lasting for about $10 \mathrm{~min}$ in a GC injector. For SPME, between 8 and 20 adult fruit flies (4-8 days old, either males or females) were placed in a $50 \mathrm{~mL}$ glass vial covered in aluminum foil and exposed to the fiber for $120 \mathrm{~min}$. Once sampling was finished, the fiber was transferred to the injection port, either of the coupled gas chromatography-electroantennogram detection (GC-EAD) or gas chromatography-mass spectrometry (GC-MS) system, operating under the conditions described below. The thermal desorption duration of volatiles from the fiber was $2 \mathrm{~min}$. Headspace SPME samples were collected from females and males of $R$. batava and analyzed by GC-EAD using antennae of both sexes. 


\subsection{GC-EAD Detection}

GC-EAD (gas chromatograph Clarus 500, PerkinElmer, Waltham, MA, USA; EAD, Ockenfels Syntech GmbH, Buchenbach, Germany) was used to identify EAD-active compound(s) in the headspace of R. batava flies and to test EAD activity of synthetic compounds.

The GC effluent was divided using a splitter into two equal parts, allowing simultaneous flame ionization and EAD detection of the separated volatile compounds. One part of the column effluent was directed to the flame ionization detector (FID). A nitrogen make-up gas at a flow rate of $5 \mathrm{~mL} / \mathrm{min}$ was used to enhance FID performance. Another part of the effluent was introduced into a purified and humidified air stream flowing at $0.5 \mathrm{~m} / \mathrm{s}$ through a glass tube over antenna preparation. The flies used in GC-EAD analyses were not chilled or anesthetized prior to use. Glass capillary electrodes were filled with $0.9 \% \mathrm{NaCl}$ saline (Ilsanta, Vilnius, Lithuania) and grounded via a silver wire. An indifferent electrode was inserted into the severed head of the fly. The recording electrode, connected to a high-impedance DC amplifier (IDAC-4, Ockenfels Syntech GmbH, Buchenbach, Germany) with automatic baseline drift compensation was brought into contact with the distal end of the fly antenna. The antennal and the FID signals were recorded simultaneously, stored and analyzed using GcEad V. 4.4 software (Synthech, Ockenfels Syntech GmbH, Buchenbach, Germany). The male and female antennae responses to male odors and to synthetic (+)- and (-)- $\delta$-heptalactones, as well as male antenna responses to female odors were tested. Flies from 4 to 7 days old were used in the tests. Each EAD test was replicated three times and each antenna used was from a different fly.

For headspace analysis, the GC was equipped with a DB-Wax capillary column $(30 \mathrm{~m} \times 0.25 \mathrm{~mm}$ $\times 0.25 \mu \mathrm{m}$; Agilent Technologies, Santa Clara, CA, USA). The injector and the detector temperatures were set to $240^{\circ} \mathrm{C}$. The oven temperature was maintained isothermally at $40^{\circ} \mathrm{C}$ for $1 \mathrm{~min}$; afterward, it was raised to $240{ }^{\circ} \mathrm{C}$ at a rate of $10^{\circ} \mathrm{C} / \mathrm{min}$, then maintained isothermally for $13 \mathrm{~min}$. Hydrogen, at a flow rate $1.5 \mathrm{~mL} / \mathrm{min}$, was used as a carrier gas.

After the identification of EAD active compounds and revealing the potential presence of enantiomers, a Rt ${ }^{\circledR}-b D E X s m$ column $(30 \mathrm{~m} \times 0.25 \mathrm{~mm} \times 0.25 \mu \mathrm{m}$, Restek Corporation, Bellefonte, PA, USA) was used instead of the previous column. The stationary chiral phase of the column was composed of 2,3-di-O-methyl-6-O-tert-butyl dimethylsilyl $\beta$ cyclodextrin, added into $14 \%$ cyanopropylphenyl/86\% dimethyl polysiloxane. Cyclodextrin-based GC stationary phases provide excellent separation for a wide range of chiral compounds and are the most widely used [17]. In this case, the injector and the detector temperatures were set to $230{ }^{\circ} \mathrm{C}$. The oven initial temperature was $90{ }^{\circ} \mathrm{C}$, then programmed to $200{ }^{\circ} \mathrm{C}$ at a rate of $3{ }^{\circ} \mathrm{C} / \mathrm{min}$.

\subsection{GC-MS Analysis}

A Shimadzu GC-2010 gas chromatograph coupled with a Shimadzu MS-QP 2010 Plus mass selective detector (Shimadzu, Kyoto, Japan) was used. The EAD active compound present in the $R$. batava flies' headspace was analyzed using the GC equipped with a Stabil-Wax column $(30 \mathrm{~m} \times$ $0.25 \mathrm{~mm} \times 0.25 \mu \mathrm{m}$, Restek Corporation, Bellefonte, PA, USA). For analysis of synthetic enantiomers as well as those present in the headspace, we used a Rt ${ }^{\circledR}$-bDEXsm column $(30 \mathrm{~m} \times 0.25 \mathrm{~mm} \times 0.25 \mu \mathrm{m}$, Restek Corporation, Bellefonte, PA, USA). The GC was operated under the same conditions as described in in Section 2.3, except that helium was used as the carrier gas, at a flow rate $1.5 \mathrm{~mL} / \mathrm{min}$. Electron ionization spectra were acquired at an electron energy of $70 \mathrm{eV}$ and the interface and ion source temperatures were held isothermal at $250{ }^{\circ} \mathrm{C}$. The headspace EAD active compound was identified by comparing its mass spectral data with those available from the library of National Institute of Standards and Technology (NIST, version 2.0, National Institute of Standards and Technology, Gaithersburg, MD, USA) and comparing the retention index with that of the synthetic standard compound. The retention index [18] of the $\delta$-heptalactone was calculated using the retention data from $C_{8}-C_{28} n$-alkanes solution (Sigma-Aldrich Sweden) obtained under the same chromatographic parameters as those used for the analysis of the headspace samples. 


\subsection{Synthesis}

Methanolysis of tetrahydro-2-H-pyran-2-one (1), followed by Swern oxidation according to Reid et al. (2018) [19], yielded methyl 5-oxo-pentanoate(2) which was transformed to 6-ethyltetrahydro-2H-pyran-2-one ( $\delta$-heptalactone) (3) in both enantiomeric forms by $\mathrm{N}, \mathrm{N}$-dibutylnorephidrine catalysed alkylation with diethylzinc followed to lactonization according to Soai et al. (1988) [20] (Figure 1). The enantiomeric excess was determined by chiral GC (hydrodex B 6TBDM column, initial temperature $85^{\circ} \mathrm{C}$ hold for $30 \mathrm{~min}$, afterwards raised to $95^{\circ} \mathrm{C}$ at a rate of $1{ }^{\circ} \mathrm{C} / \mathrm{min}$ and then raised to $230^{\circ} \mathrm{C}$ at a rate of $30^{\circ} \mathrm{C} / \mathrm{min}$ ) (Table 1 ).



Figure 1. Synthesis of (+)- and (-)- $\delta$-heptalactones.

Table 1. Yield and purity of $\delta$-heptalactones.

\begin{tabular}{ccccc}
\hline Catalyst & Product & Yield & ee $^{\mathbf{1}}$ & CP $^{\mathbf{2}}$ \\
\hline$(1 R, 2 S)-(+)-N, N$-dibutylnorephidrine & $(\mathrm{R})-(+)-3$ & $35 \%$ over 2 steps & $84 \%$ & $97 \%$ \\
$(1 S, 2 R)-(-)-N, N$-dibutylnorephidrine & $(\mathrm{S})-(-)-3$ & $32 \%$ over 2 steps & $86 \%$ & $96 \%$ \\
\hline
\end{tabular}

${ }^{1}$ Enantiomeric excess; ${ }^{2} \mathrm{CP}$, chemical purity, indicates percentage of both enantiomers.

$\mathrm{R}_{\mathrm{f}}=0.30\left(\mathrm{Et}_{2} \mathrm{O} /\right.$ pentane $\left.3: 1\right)$;

${ }^{1} \mathrm{H}$ NMR $\left(\mathrm{CDCl}_{3}, 400 \mathrm{MHz}\right) \delta 4.26-4.19(1 \mathrm{H}, \mathrm{m}, \mathrm{CH}), 2.63-2.54(1 \mathrm{H}, \mathrm{m}, \mathrm{CHH}), 2.50-2.36(1 \mathrm{H}, \mathrm{m}$, $\mathrm{CHH}), 1.97-1.47\left(6 \mathrm{H}, \mathrm{m}, 3 \mathrm{CH}_{2}\right), 1.00\left(3 \mathrm{H}, \mathrm{t}, J=7.5 \mathrm{~Hz}, \mathrm{CH}_{3}\right)$;

${ }^{13} \mathrm{C} \mathrm{NMR}\left(\mathrm{CDCl}_{3}, 100 \mathrm{MHz}\right) \delta 171.9(\mathrm{C}), 81.8(\mathrm{CH}), 29.4\left(\mathrm{CH}_{2}\right), 28.7\left(\mathrm{CH}_{2}\right), 27.2\left(\mathrm{CH}_{2}\right), 18.4\left(\mathrm{CH}_{2}\right)$, $9.3\left(\mathrm{CH}_{3}\right)$;

EIMS m/z $128\left(5,[\mathrm{M}]^{+}\right), 100$ (25), 99 (100), 71 (72), 70 (33), 57 (15), 56 (38), 55 (43), 43 (36), 42 (64), 41 (43), 39 (23).

$$
\begin{aligned}
& (R)-(+)-(3): \\
& {[\alpha]_{\mathrm{D}}^{20}=+40.4 \text { ( c 1.61, THF); }} \\
& e e=84 \% . \\
& (S)-(-)-(3): \\
& \left.[\alpha]_{\mathrm{D}}^{20}=-41.2 \text { ( c } 1.62, \mathrm{THF}\right) \\
& e e=86 \% .
\end{aligned}
$$

\subsection{EAG Dose-Response}

Using the same electrophysiological recording setup and the same antennal preparation technique, electroantennogram (EAG) dose-responses of male and female $R$. batava to the synthetic $\delta$-heptalactone were recorded.

The compound was tested at doses of $10^{-5}, 10^{-4}, 10^{-3}$ and $10^{-2} \mu \mathrm{L}$ following the application of $10 \mu \mathrm{L}$ solution on a piece of filtered paper $\left(5 \times 45 \mathrm{~mm}\right.$ ) (Whatman ${ }^{\circledR} 1$, Kent, UK) and placed to a Pasteur pipette (Gmbh + Co Kg, Wertheim, Germany). Hexane solutions were prepared via the 10-step dilution of the previous solution. The four doses were tested in ascending order. A solvent blank (10 $\mu \mathrm{L}$ of hexane after evaporation) was tested as a control stimulus both at the beginning and the end of stimulation. The peak voltage amplitude was recorded during the puff delivery of each stimulus as an antenna response. Each stimulation was followed by at least a $1 \mathrm{~min}$ purge period of filtered air to ensure the recovery of the antennal receptors. Each EAD test was replicated five times and each antenna used was from a different fly. The EAG response $(\mathrm{R})$ to the EAD-active compound dose was calculated according to the formula $R=R A-\left(R C_{1}+R C_{2}\right) / 2$, where $R A$ is the EAG response to 
the EAD active compound and RC1 and RC2 are EAG responses to the first and the second control stimuli, respectively.

\subsection{Field Assay}

An organic sea buckthorn plantation in Stacijava village, Molètai district, Lithuania was chosen for the field assay. McPhail (Pherobank, Wijk bij Duurstede, The Netherlands) traps, which are designed for catching flies, were used. Flies are attracted by the pheromone loaded in a dispenser and placed in a holder inside a trap. The attracted flies fly into the trap through an inverted funnel at the base of the trap, remained attracted by the pheromone and the daylight and do not find their way out. After a while, the flies fall into a soapy water solution at the base of the trap and drown (Figure 2).

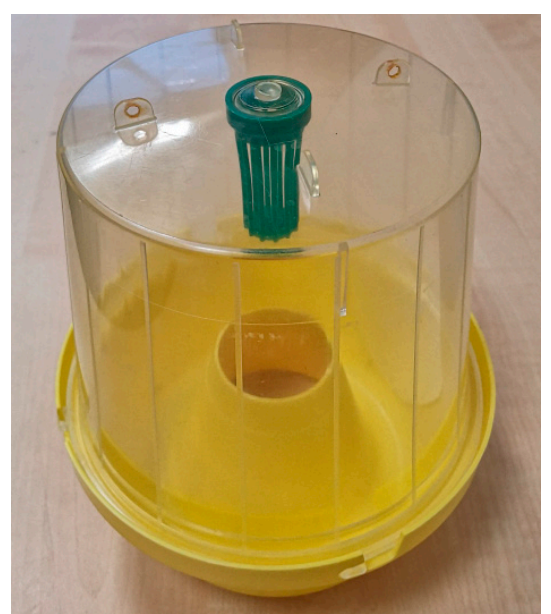

(a)

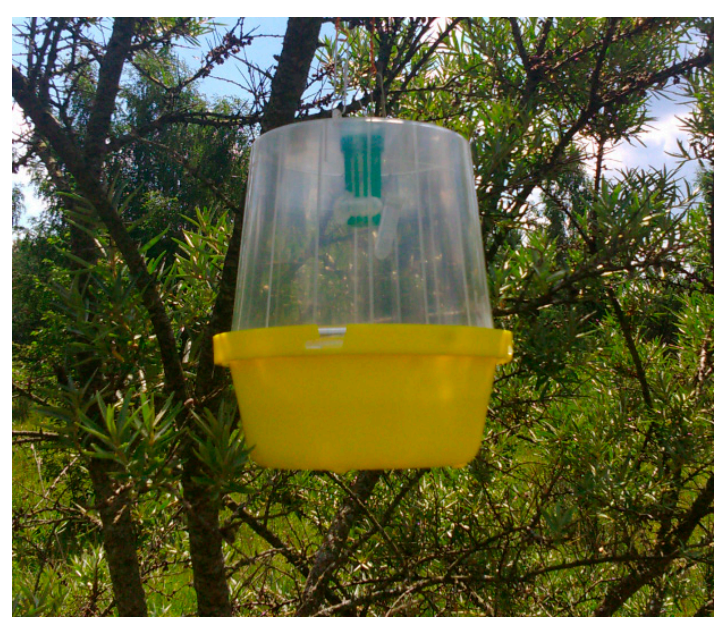

(b)

Figure 2. The McPhail trap: (a) empty trap and (b) trap fixed on the branch of sea buckthorn (Hippophae rhamnoides).

Red rubber dispensers with inner diameters of $7.1 \mathrm{~mm}(5 \times 11 \mathrm{~mm})$, Pherobank, Wijk bij Duurstede, the Netherlands) were loaded with $25 \mu \mathrm{L}$ of (-)- $\delta$-heptalactone dissolved in $50 \mu \mathrm{L}$ hexane. Control dispensers were loaded with the same amount of the solvent. For $20 \mathrm{~min}$, the solvent was allowed to evaporate. Following evaporation, unloaded dispenser was inserted in each loaded dispenser to reduce emission of the test compound. Dispensers were placed into traps and, after a three-day period, were placed in the plantation at a distance of at least $4 \mathrm{~m}$ between the test and control traps and at a distance between such couples of approximately $50 \mathrm{~m}$. Three pheromone-baited and three control traps were used. The field assay was conducted from 30 July to 20 August 2019, during flight period of R. batava flies [21]. The traps were inspected twice a week and the flies caught were taken to the laboratory for sex determination.

\subsection{Statistical Analysis}

EAG amplitudes of $R$. batava antennae of both sexes were compared using a Mann-Whitney U test at the level of significance $\alpha=0.05$. Field assay data of $R$. batava daily catches were transformed $(x+0.5)^{1 / 2}$ and a general linear model (GLM) was used to evaluate the sex (male or female) and treatment type (pheromone and control) effect on the attraction of flies [22]. The statistical analysis was performed using Statistica 6.0 and the GLM test was carried out by Statistica 13.5 software (StatSoft, Inc., Tulsa, OK, USA). 


\section{Results}

\subsection{EAD Active Compound}

Coupled GC-EAD analysis of headspace volatiles collected from live either male or female adult R. batava showed that antennae of both sexes responded strongly to the single compound in the headspace of males (Figure 3). The antennae of males did not respond to any compound in the female headspace.



Figure 3. Gas chromatography-electroantennogram detection (GC-EAD) response of male and female Rhagoletis batava to headspace volatiles of R. batava males. FID, flame ionization detector; EAD, electroantennographic detector; DB-Wax capillary column $(30 \mathrm{~m} \times 0.25 \mathrm{~mm} \times 0.25 \mu \mathrm{m}$; Agilent Technologies, Santa Clara, CA, USA); each EAD test was replicated three times and each antenna used was from a different fly.

GC-MS analyses of the volatiles collected from $R$. batava males demonstrated that the EAD active compound (retention index (RI) 1882 on Stabil-Wax column) produced a weak molecular ion at $m / z$ 128. Significant ions included $m / z$ (\%) 42 (90), 55 (60), 71 (80) and 99 (100). The RI and mass spectrum of this compound matched those of the synthetic standard of $\delta$-heptalactone.

\subsection{EAD Active Enantiomer of $\delta$-Heptalactone}

Couplet GC-EAD analysis of synthetic enantiomers of $\delta$-heptalactone revealed a strong response of $R$. batava fruit flies of both sexes to the single enantiomer only. No response to (+)- $\delta$-heptalactone was registered and high sensitivity to (-)- $\delta$-heptalactone was recorded (Figure 4$)$.

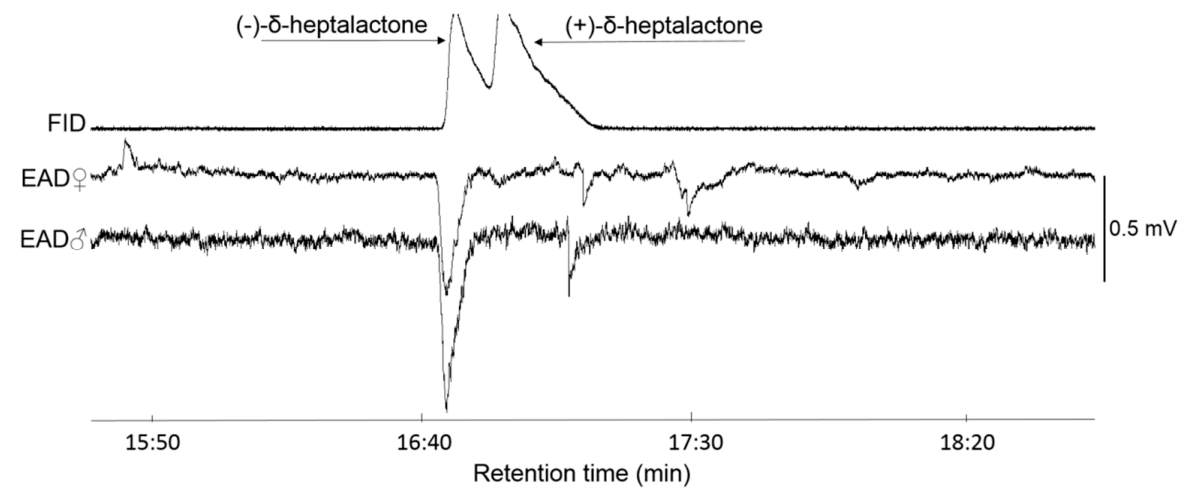

Figure 4. GC-EAD response of male and female $R$. batava to synthetic enantiomers of $\delta$-heptalactone. Enantiomeric separation of $\delta$-heptalactone was conducted using an $\mathrm{Rt}^{\circledR}$-bDEXsm column (30 $\mathrm{m} \times$ $0.25 \mathrm{~mm} \times 0.25 \mu \mathrm{m}$, Restek Corporation); each EAD test was replicated three times and each antenna used was from a different fly. 


\subsection{Active Enantiomer of $\delta$-Heptalactone in R. batava}

The enantiomeric composition of the insect-produced compound was determined to be $(-)-\delta$-heptalactone by comparison of the retention time of natural $\delta$-heptalactone with synthetic isomers on a chiral $\mathrm{Rt}^{\circledR}$-bDEXsm capillary column (Figure 5).

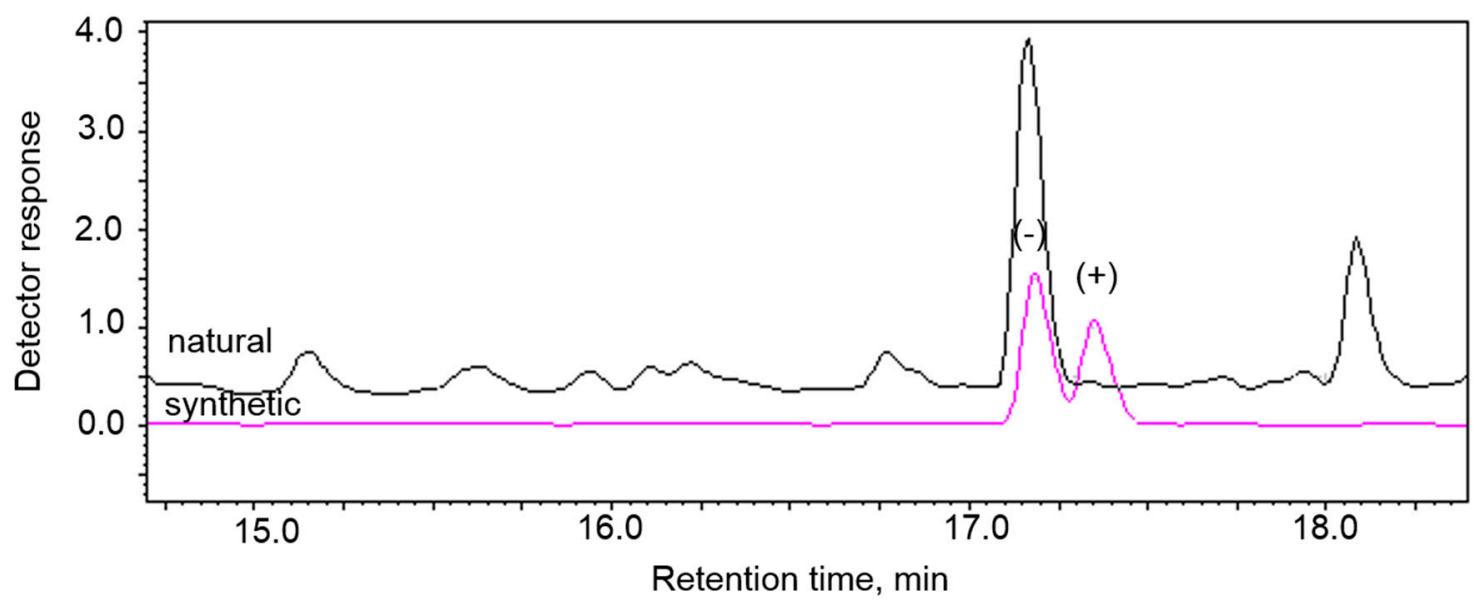

Figure 5. GC analyses of natural and synthetic enantiomers of $\delta$-heptalactone on chiral $\mathrm{Rt}^{\circledR}{ }^{\circledR}$-bDEXsm capillary column.

\subsection{Dose Response}

The sensitivity of males and females to the lowest dose tested was different, with males being more sensitive than females (Mann-Whitney $U$ test, $Z=-2.08, p=0.037$ ). At higher doses, no differences in EAG responses between sexes was recorded (Mann-Whitney $U$ test, $Z=-0.3203,0.2402$ and 0.8807 at doses of $1 \times 10^{-4}, 1 \times 10^{-3}$ and $1 \times 10^{-2} \mu \mathrm{L}$, respectively, $p>0.05$ ) (Figure 6).

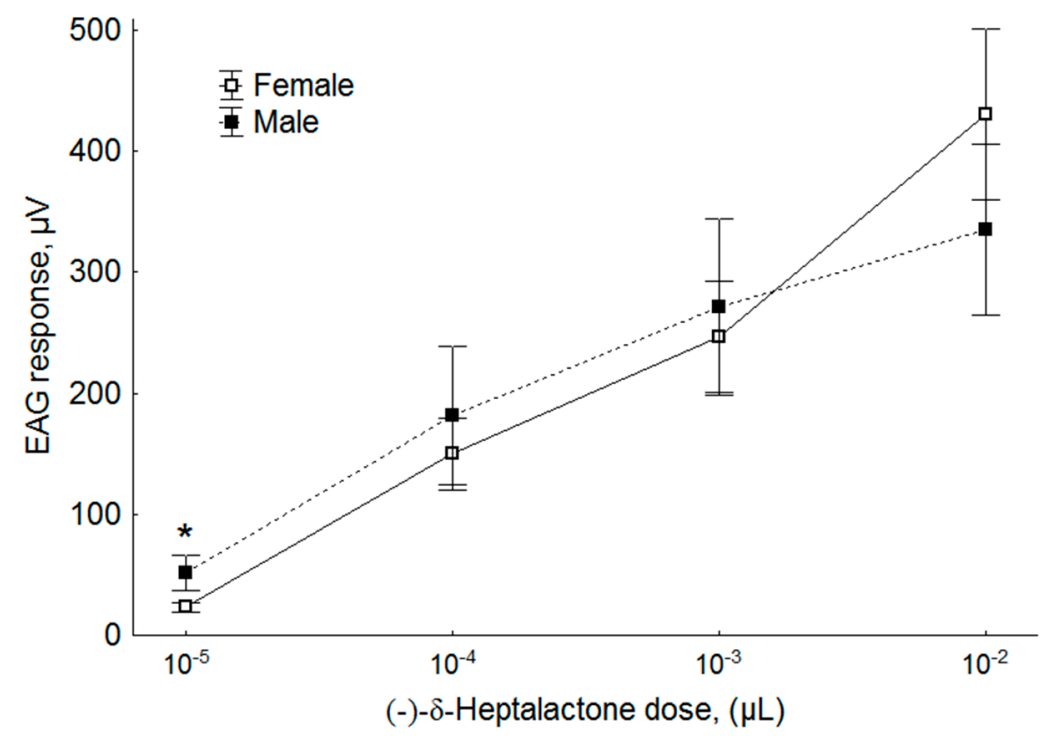

Figure 6. Electroantennogram (EAG) responses (mean amplitude \pm standard error (SE), $\mathrm{mV}$ ) of male and female $R$. batava to different doses $\left(1 \times 10^{-5}\right.$ to $\left.1 \times 10^{-2} \mu \mathrm{L}\right)$ of synthetic $(-)-\delta$-heptalactone. The asterisk denotes significant differences in EAG responses between sexes (Mann-Whitney U Test, $\mathrm{Z}=-2.08 p=0.037$ ); each EAD test was replicated five times and each antenna used was from a different fly. 


\subsection{Behavioural Test under Field Conditions}

Sex determination of the specimens caught by the traps revealed that both males and females of $R$. batava flies were captured. In traps loaded with (-)- $\delta$-heptalactone, we caught 61 male and 63 females and the number of insects caught exceeded that of control traps by 2.5 times (Figure 7).

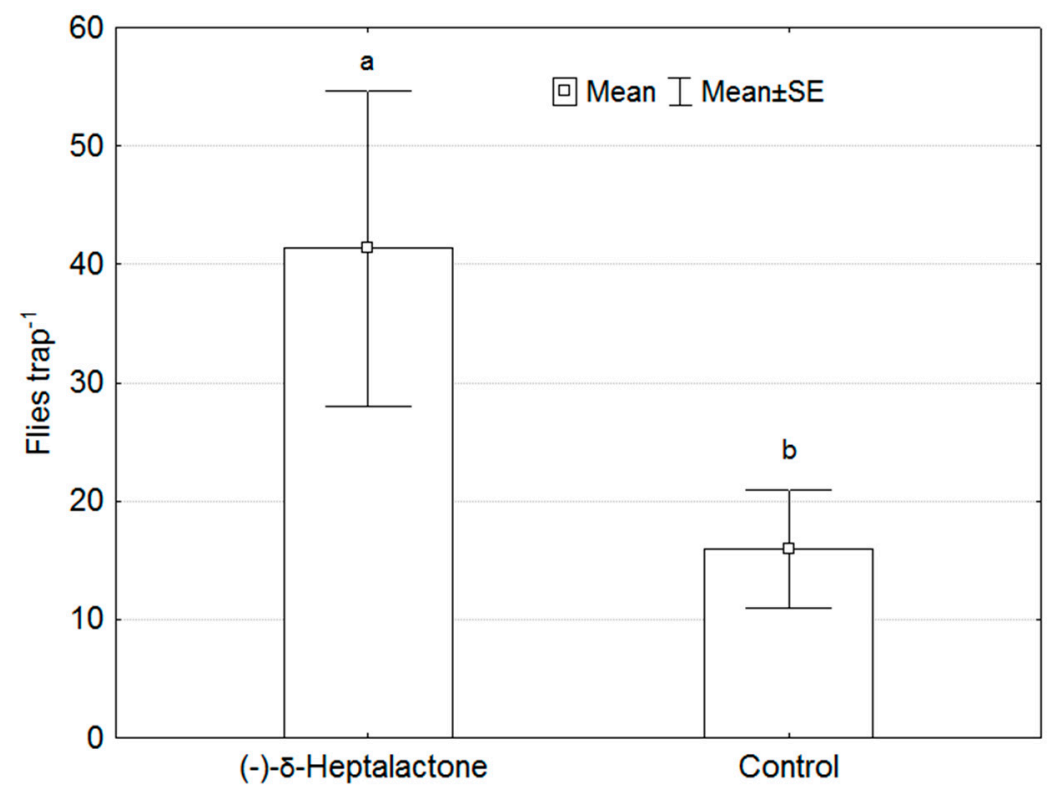

Figure 7. Field catches of Rhagoletis batava in McPhail traps. Different letters indicate statistically significant difference (general linear model, $\mathrm{F}=7.013, p=0.027$ ); intervals mark SE; $n=3$ for each type; trapping period lasted from 30 July to 20 August 2019.

Statistical data evaluation by GLM revealed that the treatment type (pheromone and control) significantly influenced the attraction of flies $(\mathrm{F}=7.013, p=0.027)$ whereas attraction between the sexes (male or female) was not significantly different $(\mathrm{F}=0.061, p=0.812)$. Twenty \pm 6 (mean of specimens per trap \pm standard error of mean) males and $21 \pm 7$ females were caught by the traps baited with (-)- $\delta$-heptalactone and $7 \pm 3$ males and $8 \pm 2$ females we detected in the control traps. As the traps contained fruit flies of both sexes, we concluded that (-)- $\delta$-heptalactone functions as an aggregation pheromone.

\section{Discussion}

In the majority of Tephritidae species, mating is mediated by a combination of chemical, acoustic and visual cues. Pheromones play a key role during the mate-searching phase and, in general, they are produced by males to attract females $[15,23]$. The results of our experiments showed that $R$. batava antennae from both sexes react to a single compound, $\delta$-heptalactone, detected exclusively in the headspace emissions from males. No significant difference in EAG responses between sexes was recorded except testing the lowest $10^{-5} \mu \mathrm{g}$ dose and males showed higher sensitivity than females. We assume that ability of males to sense lower dose of pheromone could allow them to detect single pheromone releasing males and to form groups of individuals for the purpose of mating, while females detect aggregations of the calling males perceiving higher concentrations of a pheromone. The responses of antennae to synthetic (-)- and (+)-enantiomers of $\delta$-heptalactone revealed that only $(-)-\delta$-heptalactone was EAD active while no response was registered to $(+)-\delta$-heptalactone. Usually, receptors activated by optically active compounds show preferential of varying degrees to one of the enantiomers or respond at a similar level to both enantiomers [24-27]. Until date, no response to one enantiomer of an enantiomer pair has been reported in limited number of insect species [24,28,29]. 
The attractiveness of the electrophysiologically active compound was also registered for both sexes under field conditions, revealing that the compound functions as a long-range attraction pheromone. Considering the definition given by Wyatt, "When male insects pheromone-call they often attract males as well as females; the pheromones concerned are called aggregation pheromones even if their original function was sex attraction" [30], we argue that the pheromone is attributed to the aggregation pheromone type. Many Tephritidae species form leks [31]; however, males of some Rhagoletis species (including R. pomonella, R. rubicola and R. mendax) individually seek out females on the fruit surface [32]. During our previous project studying the seasonal flight and mating dynamics of $R$. batava flies, 1847 pairs in copula were counted [21] and often a few mating pairs or a few individuals were observed at closer distance to each other rather than distributed evenly (Figure 8, personal report). Aluja and Birke defined a "lek" as an aggregation of at least three pheromone-calling males in a clearly defined area, usually from adjacent leaves of a host or non-host plant species [33]. Further studies are needed to collect more detailed information about the spatial and temporal characteristics of groups formed in response to male-released pheromones in the natural habitat of the species.
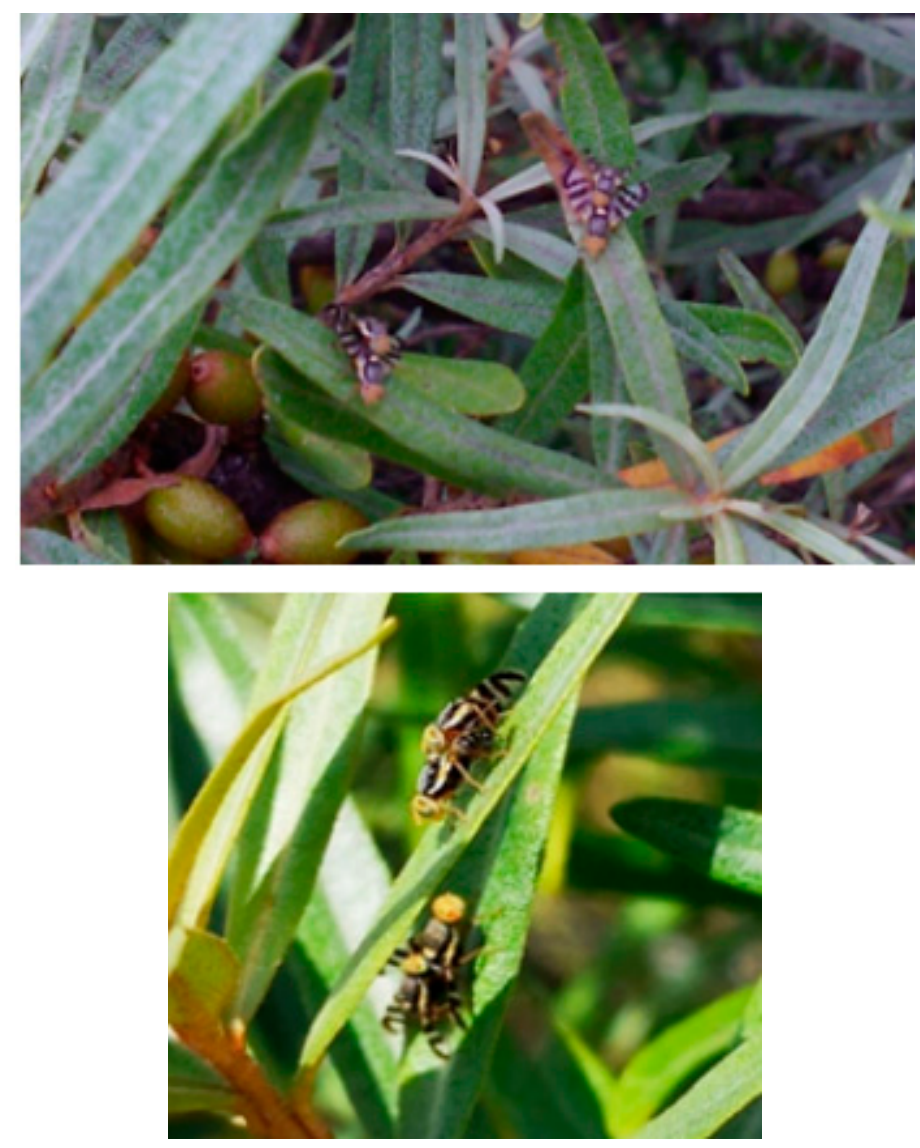

Figure 8. A few R. batava pairs in copula are commonly found near each other on adjacent leaves of a host plant Hippophae rhamnoides.

Pheromone of $R$ batava is a lactone formed by the cyclization of a hydroxyl ester [34]. To date, eight compounds bearing the lactone moiety have been reported in seven Tephritidae species, attributed to genera Anastrepha, Bactrocera, Ceratitis and Rhagoletis (Table 2). In all seven species, lactones were emitted exclusively by males (Table 2 ); hence, our data showing that (-)- $\delta$-heptalactone is a male-specific compound follows the pattern observed in other Tephritidae species. The biological activity of lactones produced by Anastrepha, Bactrocera, Ceratitis and Rhagoletis males were tested using either just females or the sex of the specimens caught in the traps was not determined; hence, information is insufficient to determine whether males respond to the lactones as well. 
To avoid toxic residues of insecticides in harvested sea buckthorn berries, biological or biotechnical control methods to decrease yield losses against $R$. batava flies are urgently required, while in organic production, biological control is only an option [35]. Different approaches could be considered including yellow sticky traps, insect sterilization and various biological antagonists, as well as semiochemical-based pest control means [36,37]. Our experimental field results showed that McPhail traps with a pheromone lure were over twice as efficient as trapping $R$. batava flies with control traps. Our previous work revealed a blend composed of nine EAD active yeast volatiles that attracted $R$. batava flies under laboratory conditions [38]. Further work is needed to increase lure efficiency by combining the pheromone with berry-associated yeast odors to develop a semiochemical-based trap for monitoring and control of R. batava flies in buckthorn orchards.

Table 2. Lactones produced by Tephritidae species.

\begin{tabular}{|c|c|c|c|c|}
\hline Compound Name & CAS No. ${ }^{1}$ & Species & Emitter & Reference \\
\hline Lavender lactone & $1073-11-6$ & Anastrepha fraterculus & M & [39] \\
\hline \multirow[t]{4}{*}{ Suspensolide } & 111351-08-7 & Anastrepha fraterculus & $\mathrm{M}$ & [39-41] \\
\hline & & Anastrepha ludens & M & [42] \\
\hline & & Anastrepha suspensa & M & [42-44] \\
\hline & & Anastrepha sp. & M & [45] \\
\hline \multirow[t]{4}{*}{ S,S-Anastrephin } & $77670-94-1$ & Anastrepha fraterculus & M & [39-41] \\
\hline & & Anastrepha ludens & M & {$[42,46-48]$} \\
\hline & & Anastrepha suspensa & $\mathrm{M}$ & {$[42-44,46,48]$} \\
\hline & & Anastrepha sp. & M & [45] \\
\hline \multirow[t]{4}{*}{ S,S-Epianastrephin } & $77670-93-0$ & Anastrepha fraterculus & M & [39-41] \\
\hline & & Anastrepha ludens & M & {$[42,46,47]$} \\
\hline & & Anastrepha suspensa & $\mathrm{M}$ & {$[42-44,46,48]$} \\
\hline & & Anastrepha sp. & M & [45] \\
\hline $\begin{array}{l}\text { (E)-5-(3,6-heptadienyl)-dihydro- } \\
\text { 2(3H)-furanone }\end{array}$ & $81693-14-3$ & Bactrocera cucurbitae & M & [49] \\
\hline Dihydro-3-methylfuran-2(3H)-one & $1679-47-6$ & Ceratitis capitata & M & [50] \\
\hline$\delta$-Hexalactone & $823-22-3$ & Rhagoletis completa & M & [15] \\
\hline$\delta$-Heptalactone & $3301-90-4$ & Rhagoletis completa & M & [15] \\
\hline
\end{tabular}

${ }^{1}$ Chemical Abstract Service Number; M, male.

\section{Conclusions}

$(-)-\delta$-heptalactone is emitted exclusively by males of $R$. batava flies. Only (-)-enantiomer elicited EAG responses in both sexes, whereas no response to the (+)-enantiomer was registered. Both males and females of $R$. batava were captured in traps baited with the active compound. Based on the mode of action, (-)- $\delta$-heptalactone is an aggregation pheromone, with potential for application in pest management programs of $R$. batava flies. The aggregation type of a pheromone is first reported here within the genus Rhagoletis.

Author Contributions: Conceptualization, V.B. and D.A.; methodology, V.B., S.S., L.B.-Č. and R.M.; validation, V.B., D.A. and S.S.; formal analysis, L.B.-Č. and D.A.; investigation, V.A., S.R., P.S., L.B.-Č. and D.A.; resources, V.B., S.S., L.B.-Č. and D.A.; data curation, D.A., L.B.-Č., P.S. and V.B.; writing-original draft preparation, V.B. and R.M.; writing-review and editing, all authors; visualization, L.B.-Č., S.R., V.A. S.S. and D.A.; supervision, V.B. and S.S.; project administration, V.B., D.A.; funding acquisition, R.M., V.B. and S.S. All authors have read and agreed to the published version of the manuscript.

Funding: This research received funding from European Social Fund (project no. 09.3.3-LMT-K-712-01-0099) under grant agreement with the Research Council of Lithuania (LMTLT).

Acknowledgments: Thanks to Povilas Šukys for their kind permission to collect puparia in their sea buckthorn plantation.

Conflicts of Interest: The authors declare no conflict of interest. 


\section{References}

1. Shamanskaya, L.D. Bioecology of the sea-buckthorn fly (Rhagoletis batava obscuriosa Kol.) and pest control treatment in Altai. In Proceedings of Producing Sea Buckthorn of High Quality; Natural Resources Institute Finland: Naantali, Finland, 2015; pp. 7-20.

2. Shalkevich, M.S.; Koltun, N.Y.; Pleskatsevich, R.I. Sea buckthorn pests and diseases in Belarus. In Proceedings of Producing Sea Buckthorn of High Quality; Natural Resources Institute Finland: Naantali, Finland, 2015; pp. 83-86.

3. Li, T.S.C.; Schroeder, W.R. Sea buckthorn (Hippophae rhamnoides L.): A multipurpose plant. Hort. Technol. 1996, 6, 370-380.

4. Hakeem, K.; Ozturk, M.; Altay, V.; Letchamo, W.; Musayev, M.; Mamedov, N. An alternative potential natural genetic resource: Sea buckthorn [Elaeagnus rhamnoides (syn.: Hippophae rhamnoides)]. In Global Perspectives on Underutilized Crops; Ozturk, M., Hakeem, K.H., Ashraf, M., Ahmad, M.S.A., Eds.; Springer: Cham, Switzerland, 2018; pp. 25-82. [CrossRef]

5. Small, E.; Catling, P.M.; Li, T.S.C. Blossoming treasures of biodiversity: 5. Sea Buckthorn (Hippophae rhamnoides)-An ancient crop with modern virtues. Biodiversity 2002, 3, 25-27. [CrossRef]

6. Ruan, C.J.; da Silva, J.A.T.; Jin, H.; Li, H.; Li, D.Q. Research and biotechnology in sea buckthorn (Hippophae spp.). Med. Aromat. Plant Sci. Biotechnol. 2007, 1, 47-60.

7. Bal, L.M.; Meda, V.; Naik, S.N.; Satya, S. Sea buckthorn berries: A potential source of valuable nutrients for nutraceuticals and cosmoceuticals. Food Res. Int. 2011, 44, 1718-1727. [CrossRef]

8. Kaur, T.; Singh, G.; Kapoor, D.N. A review on pharmacognostic, phytochemical and pharmacological data of various species of Hippophae (Sea buckthorn). Int. J. Green Pharm. 2017, 11, s62-s75.

9. Eagle, D. Are quality standards necessary for sea buckthorn-A business perspective. In Proceedings of Producing Sea Buckthorn of High Quality; Natural Resources Institute Finland: Naantali, Finland, 2015; pp. $44-48$.

10. Brūvelis, A. Experiences about sea buckthorn cultivation and harvesting in Latvia. In Proceedings of Producing Sea Buckthorn of High Quality; Natural Resources Institute Finland: Naantali, Finland, 2015; pp. 36-41.

11. Toth, M.; Lerche, S.; Holz, U.; Kerber, A.; Henning, R.; Voigt, E.; Kelemen, D. Addition of synthetic feeding attractant increases catches of Rhagoletis batava Hering and Carpomyia schineri Loew. in fluorescent yellow sticky traps. Acta Phytopathologica et Entomologica Hungarica 2016, 51, 69-76. [CrossRef]

12. Zhao, B.; Cheng, T.M.; Li, S.S.; Su, Z.; Wei, J.R. Attractants for Rhagoletis batava obseuriosa, a fruit fly pest of sea buckthorn. Int. J. Pest Manag. 2019, 65, 324-331. [CrossRef]

13. Papaj, D.R.; Garcia, J.M.; AlonsoPimentel, H. Marking of host fruit by male Rhagoletis boycei cresson flies (Diptera: Tephritidae) and its effect on egg-laying. J. Insect Behav. 1996, 9, 585-598. [CrossRef]

14. Sarles, L.; Boullis, A.; Fassotte, B.; Lognay, G.; Verhaeghe, A.; Francis, F.; Verheggen, F.J. Identification of walnut husk (Juglans regia L.) volatiles and the behavioural response of the invasive Walnut Husk Fly, Rhagoletis completa Cresson. Pest Manag. Sci. 2017, 73, 2100-2104. [CrossRef]

15. Sarles, L.; Fassotte, B.; Boullis, A.; Lognay, G.; Verhaeghe, A.; Marko, I.; Verheggen, F.J. Improving the monitoring of the walnut husk fly (Diptera: Tephritidae) using male-produced lactones. J. Econ. Entomol. 2018, 111, 2032-2037. [CrossRef]

16. Raptopoulos, D.; Haniotakis, G.; Koutsaftikis, A.; Kelly, D.; Mavraganis, V. Biological-activity of chemicals identified from extracts and volatiles of male Rhagoletis cerasi. J. Chem. Ecol. 1995, 21, 1287-1297. [CrossRef] [PubMed]

17. Patil, R.A.; Weatherly, C.A.; Armstrong, D.W. Chiral Gas Chromatography. In Chiral Analysis, 2nd ed.; Polavarapu, P.L., Ed.; Elsevier: Amsterdam, The Netherlands, 2018; pp. 468-505. [CrossRef]

18. Chalk, S.J. Retention index, I in column chromatography. In IUPAC. Compendium of Chemical Terminology, the "Gold Book"; McNaught, A.D., Wilkinson, A., Eds.; Blackwell Scientific Publications: Oxford, UK, 1997. [CrossRef]

19. Reid, B.T.; Mailyan, A.K.; Zakarian, A. Total synthesis of (+)-guadinomic acid via hydroxyl-directed guanidylation. J. Org. Chem. 2018, 83, 9492-9496. [CrossRef] [PubMed]

20. Soai, K.; Yokoyama, S.; Hayasaka, T.; Ebihara, K. Catalytic asymmetric-synthesis of alkyl substituted lactones by enantioselective and chemoselective alkylation of formylesters with dialkylzincs using n,n-dibutylnorephedrine. Chem. Lett. 1988, 843-846. [CrossRef] 
21. Aleknavičius, D.; Būda, V. Trapping peculiarities, flight and mating dynamics of sea buckhorn fruit fly (Rhagoletis batava) in Lithuania. Zemdirbyste 2019, 106, 81-86. [CrossRef]

22. Bewick, V.; Cheek, L.; Ball, J. Statistics review 9: One-way analysis of variance. Crit. Care 2004, 8, 130-136. [CrossRef]

23. Benelli, G.; Daane, K.M.; Canale, A.; Niu, C.Y.; Messing, R.H.; Vargas, R.I. Sexual communication and related behaviours in Tephritidae: Current knowledge and potential applications for Integrated Pest Management. J. Pest Sci. 2014, 87, 385-405. [CrossRef]

24. Mori, K. Significance of chirality in pheromone science. Bioorganic Med. Chem. 2007, 15, 7505-7523. [CrossRef]

25. Pask, G.M.; Romaine, I.M.; Zwiebel, L.J. The molecular receptive range of a lactone receptor in Anopheles gambiae. Chem. Senses 2013, 38, 19-25. [CrossRef]

26. Abdullah, Z.S.; Butt, T.M. Preferences of the peripheral olfactory system of western flower thrips, Frankliniella occidentalis towards stereoisomers of common plant volatiles. Chemoecology 2015, 25, 47-51. [CrossRef]

27. Guo, F.; Yu, J.; Yang, Y.Q.; Wan, X.C. Response to enantiomers of (Z3Z9)-6,7-epoxy-octadecadiene, sex pheromone component of Ectropis obliqua Prout (Lepidoptera: Geometridae): Electroantennagram test, field trapping and in silico study. Fla. Entomol. 2019, 102, 549-554. [CrossRef]

28. Leal, W.S. Enantiomeric anosmia in scarab beetles. J. Chem. Ecol. 1999, 25, 1055-1066. [CrossRef]

29. Svensson, G.P.; Oleksa, A.; Gawronski, R.; Lassance, J.M.; Larsson, M.C. Enantiomeric conservation of the male-produced sex pheromone facilitates monitoring of threatened European hermit beetles (Osmoderma spp.). Entomologia Experimentalis Et Applicata 2009, 133, 276-282. [CrossRef]

30. Wyatt, T.D. Pheromones and Animal Behaviour: Communication by Smell and Taste; Cambridge University Press: Cambridge, UK, 2003. [CrossRef]

31. Benelli, G.; Giunti, G.; Canale, A.; Messing, R.H. Lek dynamics and cues evoking mating behavior in tephritid flies infesting soft fruits: Implications for behavior-based control tools. Appl. Entomol. Zool. 2014, 49, 363-373. [CrossRef]

32. Messina, F.J.; Subler, J.K. Conspecific and heterospecific interactions of male Rhagoletis flies (Diptera, Tephritidae) on a shared host. J. Kans. Entomol. Soc. 1995, 68, 206-213.

33. Aluja, M.; Birke, A. Habitat use by adults of Anastrepha obliqua (Diptera, Tephritidae) in a mixed mango and tropical plum orchard. Ann. Entomol. Soc. Am. 1993, 86, 799-812. [CrossRef]

34. Schulz, S.; Hotling, S. The use of the lactone motif in chemical communication. Nat. Prod. Rep. 2015, 32, 1042-1066. [CrossRef]

35. Simpson, M.; Read, D.M.Y.; Gurr, G.M. Application of Chemical Cues in Arthropod Pest Management for Organic Crops. In Chemical Ecology of Insect Parasitoids; Wajnberg, E., Colazza, S., Eds.; John Wiley \& Sons, Ltd.: West Sussex, UK, 2013; pp. 266-281. [CrossRef]

36. Daniel, C. Experiences of integrated management of European Cherry Fruit Fly (Rhagoletis cerasi) and how to utilize this knowledge for Sea Buckthorn Fly (Rhagoletis batava). In Proceedings of Producing Sea Buckthorn of High Quality; Natural Resources Institute Finland: Naantali, Finland, 2015; pp. 21-30.

37. Daniel, C.; Grunder, J. Integrated management of European cherry fruit fly Rhagoletis cerasi (L.): Situation in Switzerland and Europe. Insects 2012, 3, 956-988.

38. Mozūraitis, R.; Aleknavičius, D.; Vepštaitè-Monstavičè, I.; Stanevičienè, R.; Noushin Emami, S.; Apšegaitė, V.; Radžiutè, S.; Blažytė-Čereškienè, L.; Servienè, E.; Būda, V. Hippophae rhamnoides berry related Pichia kudriavzevii yeast volatiles modify behaviour of Rhagoletis batava flies. J. Adv. Res. 2019. [CrossRef]

39. Milet-Pinheiro, P.; Navarro, D.M.A.; De Aquino, N.C.; Ferreira, L.L.; Tavares, R.F.; da Silva, R.D.C.; Lima-Mendonca, A.; Vanickova, L.; Mendonca, A.L.; Do Nascimento, R.R. Identification of male-borne attractants in Anastrepha fraterculus (Diptera: Tephritidae). Chemoecology 2015, 25, 115-122. [CrossRef]

40. Lima, I.S.; House, P.E.; do Nascimento, R.R. Volatile substances from male Anastrepha fraterculus wied. (Diptera: Tephritidae): Identification and behavioural activity. J. Braz. Chem. Soc. 2001, 12, 196-201. [CrossRef]

41. Caceres, C.; Segura, D.F.; Vera, M.T.; Wornoayporn, V.; Cladera, J.L.; Teal, P.; Sapountzis, P.; Bourtzis, K.; Zacharopoulou, A.; Robinson, A.S. Incipient speciation revealed in Anastrepha fraterculus (Diptera; Tephritidae) by studies on mating compatibility, sex pheromones, hybridization and cytology. Biol. J. Linn. Soc. 2009, 97, 152-165. [CrossRef]

42. Rocca, J.R.; Nation, J.L.; Strekowski, L.; Battiste, M.A. Comparison of volatiles emitted by male caribbean and mexican fruit-flies. J. Chem. Ecol. 1992, 18, 223-244. [CrossRef] [PubMed] 
43. Chuman, T.; Sivinski, J.; Heath, R.R.; Calkins, C.O.; Tumlinson, J.H.; Battiste, M.A.; Wydra, R.L.; Strekowski, L.; Nation, J.L. Suspensolide, a new macrolide component of male caribbean fruit-fly (Anastrepha suspensa Loew ) volatiles. Tetrahedron Lett. 1988, 29, 6561-6564. [CrossRef]

44. Lu, F.; Teal, P.E.A. Sex pheromone components in oral secretions and crop of male Caribbean fruit files, Anastrepha suspensa (Loew). Arch. Insect Biochem. Physiol. 2001, 48, 144-154. [CrossRef]

45. Baker, J.D.; Heath, R.R. NMR spectral assignment of lactone pheromone components emitted by caribbean and mexican fruit-flies. J. Chem. Ecol. 1993, 19, 1511-1519. [CrossRef]

46. Battiste, M.A.; Strekowski, L.; Vanderbilt, D.P.; Visnick, M.; King, R.W.; Nation, J.L. Anastrephin and epianastrephin, novel lactone components isolated from the sex-pheromone blend of male caribbean and mexican fruit-flies. Tetrahedron Lett. 1983, 24, 2611-2614. [CrossRef]

47. Stokes, J.B.; Uebel, E.C.; Warthen, J.D.; Jacobson, M.; Flippenanderson, J.L.; Gilardi, R.; Spishakoff, L.M.; Wilzer, K.R. Isolation and identification of novel lactones from male mexican fruit-flies. J. Agric. Food Chem. 1983, 31, 1162-1167. [CrossRef]

48. Robacker, D.C.; Ingle, S.J.; Hart, W.G. Mating frequency and response to male-produced pheromone by virgin and mated females of the mexican fruit-fly (Diptera, Tephritidae). Southw. Entomol. 1985, 10, $215-221$.

49. Ohinata, K.; Jacobson, M.; Kobayashi, R.M.; Chambers, D.L.; Fujimoto, M.S.; Higa, H.H. Oriental fruit fly(Diptera, Tephritidae) and melon fly(Diptera, Tephritidae)-Biological and chemical studies of smoke produced by males. J. Environ. Sci. Health Part A Environ. Sci. Eng. Toxic Hazard. Subst. Control 1982, 17, 197-216. [CrossRef]

50. Baker, R.; Herbert, R.H.; Grant, G.G. Isolation and identification of the sex-pheromone of the Mediterranean fruit-fly, Ceratitis capitata (Wied). J. Chem. Soc. Chem. Commun. 1985, 824-825. [CrossRef]

(C) 2020 by the authors. Licensee MDPI, Basel, Switzerland. This article is an open access article distributed under the terms and conditions of the Creative Commons Attribution (CC BY) license (http://creativecommons.org/licenses/by/4.0/). 